\title{
A STUDY OF THE ALKALOIDS \\ OF Glaucium fimbrilligerum
}

\author{
A. Kh. Yunusov and I. A. Is railov
}

UDC 547.943

Continuing a study of the alkaloid composition of G. fimbrilligerum [1] from different growth sites, we have investigated the plant collected on July 13, 1971, in the flowering period, in the environs of the village of Yurkun' (Pamir-Alai). Chloroform extraction gave $0.39 \%$ of combined alkaloids, and by separating these with respect to their solubility in organic solvents, by the preparation of salts, and by column chromatography on alumina, we isolated sanguinarine, chelenythrine, protopine, allocryptopine, isocorydine, corydine, isoboldine, and bases with $\mathrm{mp} 132-133^{\circ} \mathrm{C}$ and $200-201^{\circ} \mathrm{C}$. The base with $\mathrm{mp} 132^{\circ}-133^{\circ} \mathrm{C}$ (from methanol) has the composition $\mathrm{C}_{18} \mathrm{H}_{21} \mathrm{NO}_{3},[\alpha]_{\mathrm{D}}-62.3^{\circ}$ (c 0.78 ; chloroform) $\mathrm{R}_{f} 0.3$ [benzene- chloroform-methanol $(5: 2: 2)$ system]. The base is sparingly soluble in ether and benzene and readily soluble in alkalis. The IR spectrum shows absorption bands at 1510 and $1600 \mathrm{~cm}^{-1}$ (aromatic ring) and a broad band at $3200-$ $3600 \mathrm{~cm}^{-1}$ (hydroxy group). UV spectrum, $\lambda_{\max } 228,288 \mathrm{~nm}(\log \varepsilon 4.14,3.73)$. The mass spectrum of the base lacks the peak of the molecular ion, and the maximum ion is one with $\mathrm{m} / \mathrm{e} 192$, which is characteristic for the benzylisoquinoline alkaloids [2]. The NM R spectrum of the base taken in trifluoroacetic acid shows a three-proton doublet due to an $\mathrm{N}-\mathrm{CH}_{3}$ group at $2.64 \mathrm{ppm}(\mathrm{J}=4 \mathrm{~Hz})$, a three-proton singlet $\left(\mathrm{OCH}_{3}\right)$ at 3.51 ppm, two one-proton singlets at 6.11 and $6.42 \mathrm{ppm}$ from two para aromatic protons, and a four-proton quadruplet at 6.55 and $6.72 \mathrm{ppm}(\mathrm{J}=8 \mathrm{~Hz})$ from two equivalent pairs of ortho aromatic protons. Methylation of the base with diazomethane gave the $0, \mathrm{O}$-dimethyl ether with $\mathrm{mp} 59-60^{\circ} \mathrm{C}$ the methiodide of which, with $\mathrm{mp}$ $132-133^{\circ} \mathrm{C}$ (from methanol), was identical with an authentic sample of the methiodide of $\mathrm{O}$-methylarmepavine [3].

The facts given above indicate that the base with $\mathrm{mp} 132-133^{\circ} \mathrm{C}$ is $\mathrm{N}-$ methylcoclaurine [4], first isolated from plants of the genus Glaucium.

From the combined nonphenolic alkaloids of $G$. fimbrilligerum collected in the village of Daraut-Kurgan (Pamir-Alai) [1] we have additionally obtained a base with the composition $\mathrm{C}_{20} \mathrm{H}_{19} \mathrm{NO}_{5}, \mathrm{mp} 213-214^{\circ} \mathrm{C}$ (chloroform-methanol), $[\alpha]_{\mathrm{D}^{ \pm}} 0^{\circ}$. UV spectrum: $\lambda \max 238,290 \mathrm{~nm}(\log \varepsilon 4.13,4.01)$. The IR spectrum has absorption bands at 935 and $1040 \mathrm{~cm}^{-1}$ (methylenedioxy group, $1500 \mathrm{~cm}^{-1}$ (aromatic ring), and 3350 $3600 \mathrm{~cm}^{-1}$ (hydroxy group). The NMR spectrum shows signals in the form of a three-proton singlet at 2.20 ppm from an $\mathrm{N}-\mathrm{CH}_{3}$ group, a four-proton signal at 5.95 and $5.99 \mathrm{ppm}$ from two methylenedioxy groups, and signals from four aromatic protons at 6.66 and $6.70 \mathrm{ppm}$. The mass spectrum of the base shows the peak of the molecular ion with $\mathrm{m} / \mathrm{e} 353$ and those of ions with $\mathrm{m} / \mathrm{e} 352,335,322,304$, and 294.

The spectral features given are characteristic for alkaloids of the chelidonine type. Acetylation of the base with acetic acid gave the O-acetyl derivative. The NMR spectra of the base and its O-acetyl derivative were identical with those of chelidonine and its acetate [5]. Thus, the base that we have isolated is dl-chelidonine.

\section{LIT ERATURE CIT ED}

1. A. Kh. Yumusov, I. A. Israilov, and M. S. Yunusov, Khim. Prirodn. Soedin., 681 (1973).

2. M. Ohashi, J. M. Wilson, H. Budziki ewicz, M. Shamma, W. A. Slusarchyk, and C. Djerassi, J. Amer. Chem. Soc., 18, 2807 (1963).

3. S. Yu. Yunusov, R. A. Konovalova, and A. P. Orekhov, Zh. Obshch. Khim., 10, 641 (1940).

4. R. R. Arndt, J. Chem. Soc., 2547 (1963).

5. C-Y. Chen and D. B. MacLean, Can. J. Chem., 45, 3001 (1967).

Institute of the Chemistry of Plant Substances, Academy of Sciences of the Uzbek SSR. Translated from Khimiya Prirodnykh Soedinenii, No. 4, p. 538, July-August, 1974. Original article submitted February $19,1974$.

(C1976 Plenum Publishing Corporation, 227 West 17th Street, New York, N.Y. 10011. No part of this publication may be reproduced, stored in a retrieval system, or transmitted, in any form or by any means, electronic, mechanical, photocopying, microfilming, recording or otherwise, without written permission of the publisher. A copy of this article is available from the publisher for $\$ 15$.00. 